\section{THE PREUSS FOUNDATION SEMINAR ON VACCINE THERAPY FOR MALIGNANT PRIMARY BRAIN TUMORS \\ February 15-17, 1998, La Jolla, Calif.}

Duke University Medical Center, Division of Neurosurgery, Durham, NC 27710

The 28th Preuss Foundation Seminar, held at the Salk Institute for Biological Studies in La Jolla, California, during February 25-27, 1998, focused on the issues surrounding the development of a vaccine therapy for $\mathrm{MPBT}^{2}$. The invited participants present at the seminar consisted of a prestigious group of basic scientists, neuropathologists, and medical and surgical neuro-oncologists. The meeting Chairmen, Glenn Dranoff (Boston, Mass.) and Darell Bigner (Durham, N.C.), began by defining two overall goals for the seminar. The first goal was to present and evaluate available data in the context of the following questions:

1. To what degree will the immunologic privilege of the CNS limit a vaccination therapy?

2. To what extent is the CNS at risk for autoimmune reactions in the context of a vaccination therapy?

3. In what ways are patients with MPBT immunocompromised, and how might this impact on a vaccination therapy?

The second goal was to use this information to define the most promising vaccination approaches for MPBT and outline some well-defined clinical trials based on these approaches.

\section{Clinical Biology, Etiology, and Genetic Basis of MPBT}

The seminar opened with an overview of the clinical biology, etiology, and genetic basis of MPBT. Nicolas de Tribolet (Geneva, Switzerland) and Allan
Friedman (Durham, N.C.) reiterated the histopathologic observation that MPBT are diffuse diseases of the brain (Burger et al., 1988; Kelly et al., 1987). Thus, therapies, like surgery or focused radiation therapy, aimed at treating a narrowly restricted volume of brain intrinsically have limited value. In addition, because these therapies are relatively non-specific, patients who obtain responses from these therapies are often devastated by normal brain toxicity (Imperato et al., 1990). Thus, a rationale was provided for seeking a more specific therapeutic approach such as that promised by the intrinsic specificity of the human immune system using active immunotherapy vaccination strategies.

Paul Kleihues (Lyon, France) then presented the body of increasing evidence that subtypes of GBM exist and constitute distinct clinicopathologic entities (Biernat et al., 1997a, 1997b; Reyes-Mugica et al., 1997; Tohma et al. 1998; Watanabe et al., 1996). Primary GBM develop in older patients and typically show EGFR overexpression or amplification, PTEN mutations, MDM2 overexpression and P16 deletions. They typically contain large ischemic necrosis and show frequent Fas expression in neoplastic cells surrounding the necrosis. Another entity, secondary GBM, characterized by a progression from lower grade gliomas through to GBM, occur in younger patients, show early P53 mutations, PDGFR overexpression, and, less frequently, loss of DCC expression.

Finally, during his presentation, Fred Gage (San Diego, Calif.) reviewed the unique properties of nervous system stem cells and discussed their potential role as brain tumor progenitor cells (Hoshimaru et al., 1996; McKay, 1997). The persistence of proliferative cell populations in the brain suggest a new avenue for research and a new conceptual framework within which to discuss and design past, present, and future experiments in neuro-oncogenesis. Further delineation of these clinical, pathologic, and genetic entities will allow more rational therapy of these dif-
${ }^{1}$ Address correspondence and reprint requests to John H. Sampson, MD, PhD, Duke University Medical Center, Division of Neurosurgery, Box 3807, 4505 Busse Bldg., Durham, NC 27710.

${ }^{2}$ Abbreviations used are as follows: MPBTs, malignant primary brain tumors; GBM, glioblastoma multiforme; CTL, cytotoxic T lymphocyte;
MHC, major histocompatibility complex; EAE, experimental autoimmune encephalomyelitis; IL, interleukin; TGF, transforming growth factor; GM-CSF, granulocyte macrophage-colony stimulating factor; DCs, dendritic cells.

(Posted to Neuro-Oncology [serial online], Doc. 98-15, January 26, 1999. URL <neuro-oncology.mc.duke.edu>) 
ferent diseases and more rational target selection for vaccine therapy.

Despite the evolving definition of the genetic pedigree of MPBT, such analysis has yielded very few targets that would be appropriate for antigen-specific vaccine therapy. One tumor-specific target that has been identified in Darell Bigner's lab is the type III mutation in the EGFR gene (EGFRvIII) (Wong et al., 1992). EGFRvIII consists of an in-frame deletion of 801 basepairs in the extracellular domain of the protein. This mutation splits a codon resulting in a novel glycine amino acid at the fusion junction of the mutated protein. In addition to being clonally expressed in a large number of MPBT, this tumor-specific mutation has also been identified in carcinomas of the lung, breast, ovary, and prostate, making it an attractive target for immunotherapy (Moscatello et al., 1995; Wikstrand et al. 1995). A number of antibodies that specifically recognize this mutation have been developed and are currently undergoing preclinical evaluation as full sized antibodies or antibody fragments alone or as radioconjugates or immunotoxin conjugates (Wikstrand et al., 1995). Webster Cavenee (La Jolla, Calif.) presented data demonstrating the dramatic enhancement of tumorigenicity conferred by the introduction of the EGFRvIII gene into normal fibroblasts or malignant glioma cell lines (Batra et al., 1995; Huang et al., 1997; Nagane et al., 1996; Nishikawa et al., 1994). These mutant receptors expressed on the cell surface are constitutively autophosphorylated, albeit at a significantly decreased level compared to wild-type EGFR when activated by specific ligand.

In considering the EGFRvIII as an immunotherapeutic target, the seminar participants identified a number of advantages and disadvantages. The strongest arguments in favor of the use of EGFRvIII as an immunotherapy target are its expression in a tumor-specific manner, thus reducing the likelihood of generating nonspecific autoimmune responses against normal brain. In addition, because this molecule confers enhanced tumorigenicity, and is clonally expressed in the more malignant tumors, targeting it would direct therapy to a large proportion of brain tumor patients and to a large proportion of the most malignant cells within these patients' tumors. Although the immunogenicity of this target has not been demonstrated in human studies, it has been shown to produce high affinity antibodies in a number of different mouse strains. Darell Bigner also presented some preliminary data demonstrating that certain subclasses of these antibodies may be therapeutically effective in mouse models as well. Unfortunately, there has been no evidence to date that this mutation can serve as a CTL target. In fact, it was pointed out that the specificity that has recently been demonstrated for peptide binding to MHC molecules may severely limit the number of MHC backgrounds able to present peptides bearing this mutation for CTL recognition. Thus, although this mutation is tumor-specific, the fact that only one area of the molecule is different from the wild-type molecule may severely reduce the opportunities to develop a specific immune response solely against the mutated target. One suggestion to enhance reactivity to this target would be to use it as an MHC class II epitope. Expanding on this idea, it was suggested that if a vaccine approach were to target EGFRvIII, an ideal approach might be to try to target it throughout all arms of the immune system, including attempts to stimulate MHC class I-restricted CTL, MHC class II-restricted T helper cells, and B cells. This might be done through the use of multiple, different, and specific peptide segments designed specifically for each purpose. This peptide milieu could then be given as a subcutaneous vaccine with currently approved adjuvants or as a mixture with biologic adjuvants, including cytokines.

Other potential vaccine targets that were briefly discussed included the MAGE and GAGE antigens, common P53 mutations, and the wild-type EGFR. David Ashley (Melbourne, Australia) suggested that the high frequency of GAGE-1 expression in adult GBM and its absence in normal brain may make it a useful marker for diagnostic purposes and a target for specific immunotherapy. Because of the increased expression of the wild-type EGFR gene on most GBMs, this could also be used as a target with the advantage that immunodominant epitopes could be selected from throughout the molecule instead of being restricted to the small number of potential immunogenic peptides available in the mutated region. Although it was recognized that this would risk crossreactivity with normal tissues that also expressed wildtype EGFR, the formal possibility that an immune response could be directed in a specific manner to tumors displaying this antigen was considered. Olivera Finn (Pittsburgh, Pa.) also reviewed her work on the development of vaccines based on the MUC1 antigen (Bohm et al., 1997; Finn et al., 1995).

\section{Risk of Inducing Autoimmune Encephalomyelitis with a Vaccination Strategy}

One of the perceived risks to the development of an active immunotherapy approach to MPBT is the potential induction of deleterious cross-reactivity to normal antigens within the CNS with the subsequent development of an inflammatory response characteristic of EAE. Given the range of successful protocols for the induction of EAE in animal models, including nonhuman primates challenged with human GBM tissue (Bigner et al., 1981) and the proven susceptibility of humans to post-vaccination encephalomyelitis (Pasteur, 1885; Remlinger, 1904, 1905; Stuart and Krikorian, 1930), this possibility must play a signifi- 
cant role in the development of such vaccines and the conduct of clinical trials in this area. In order to clarify the issues that might influence the level of this risk in the context of a vaccination protocol for MPBT, $M$. Racke (St. Louis, Mo.) was asked to review the current data in this field. Evidence that the human species is susceptible to EAE was presented by Racke based on clinical trials that were attempting to induce tolerance to myelin-basic protein (Romine and Salk, 1983) and by Paul Kleihues and Darell Bigner based on a number of previous active immunotherapy clinical trials in patients with MPBT where some evidence of EAE in humans could be defined (Bloom et al., 1973; Trouillas, 1973). It has become increasingly evident that there are several CNS antigens that can induce autoimmune disease of the CNS in laboratory animals. Although myelin basic protein is the most common antigenic trigger, myelin proteolipid protein (Tuohy et al., 1988; Waksman et al., 1954), myelin oligodendrocyte glycoprotein (Linington et al., 1993), glial fibrillary acidic protein (Berger et al., 1997), and S-100 $\beta$ (Wekerle et al., 1994) are also sufficient antigens for the induction of EAE. He also presented data demonstrating that myelin antigens associated with oligodendrocytes, when used as immunogens, were likely to induce a paralytic illness, whereas antigens restricted to neurons or astrocytes often resulted in inflammation within the CNS without paralysis or, in some cases, no inflammation at all (Borrow et al., 1995). Thus, it was suggested that strategies using recombinant antigens from carefully isolated astrocytic neoplasms would be less likely to induce paralytic illness.

\section{Immunosuppression in Patients with MPBT}

It was agreed by all participants that in order to develop an efficacious vaccine strategy a clear definition of the immunologic deficiencies of brain tumor patients, at various stages, was necessary. W. Brooks (Lexington, Ky.) and T. Roszman (Lexington, Ky.) began this session by reviewing their work in this area from the past two and one-half decades and the relevant work of others. Individuals harboring a MPBT manifest a variety of in vivo and in vitro immunological defects characteristic of polarization within the Tcell compartment. These defects include an impaired delayed-type hypersensitivity to recall and neoantigens (Brooks et al., 1972, 1974; Mahaley, Jr. et al., 1977; Menzies et al., 1980; Miescher et al., 1986), diminished T-cell proliferative responsiveness to a variety of mitogens and antigens (Braun et al., 1982; Brooks et al., 1972, 1974; Elliott et al., 1987, 1990; Mahaley, Jr. et al., 1977; Miescher et al., 1986; Roszman and Brooks, 1980; Roszman et al., 1982, 1992; Thomas et al., 1975; Young et al., 1976), reduced lymphocyte protein synthesis (Menzies et al., 1980), lymphopenia secondary to enhanced activated T-cell apoptosis
(Brooks et al., 1976, 1977; Mahaley, Jr. et al., 1977), impaired T-cell second messenger signaling (Morford et al., 1997), and an inability of appropriately stimulated T cells to secrete IL-2 or express the high affinity IL-2 receptor (Elliott et al., 1987, 1990, 1992). These findings suggest an intrinsic defect in the TH-1 cytokine response that results in diminished cell-mediated immunity that can be correlated with tumor volume. Typically, the impairment in T-cell reactivity observed at initial diagnosis improves following cytoreduction only to reappear with recurrence of the tumor (Brooks et al. 1972, 1974). Some evidence suggests that the suppression of cell-mediated immunity in these individuals occurs subsequent to malignant transformation and is contingent on the secretion of immunomodulatory moieties by malignant gliomas. This hypothesis is strengthened by the observation that similar in vitro defects can be induced in $\mathrm{T}$ cells obtained from normal individuals subsequent to exposure of glioma culture supernatants. While there are reports that TGF- $\beta$ (Bodmer et al., 1989; de Martin et al., 1987; Fontana et al., 1984; Wrann et al., 1987), IL-10 (Hishii et al., 1995; Huettner et al., 1995), and prostaglandin E2 (Alleva et al., 1994) are responsible for the inhibition of T-cell function with glioma culture supernatants, Brooks and Roszman have been unable to confirm this. It appears that the suppressive factor(s), as defined by Brooks and Roszman, is either multimeric or possibly binds to carrier proteins. Further work done in collaboration with G. Shearer (National Cancer Institute) shows that glioma culture supernatant alters monocyte secretion of cytokines as well. Thus, IL-10 is increased, and IL-12 is decreased. Collectively, these data support the view that patients with gliomas have a deficiency in cell-mediated immunity and more specifically a defect in TH-1 rather than in TH-2 function. The results further suggest that the gliomas secrete a factor(s) that can impinge on monocytes or TH-1 cells as well as induce monocytes to produce cytokines that decrease TH-1 function.

In addition to immunosuppressive factors secreted by MPBT, the potential immunosuppressive role of cell surface proteins such as CD95 ligand was discussed. P.-Y. Dietrich (Geneva, Switzerland) presented data demonstrating that Fas ligand (FasL) is expressed by human astrocytoma cells in vivo and that FasLexpressing astrocytoma cell lines in vitro and tumor cells ex vivo efficiently kill Fas-bearing cells such as lymphocytes (Saas et al., 1997). Thus lymphocyteastrocytoma cell-contact events that mediate a FasLinduced lymphocyte apoptosis may play a major role in inhibiting a cell-mediated immune response against MPBT at the tumor site.

With this basic infrastructure of background information relevant to the development of a vaccine against MPBTs, vaccine approaches currently being used in other human neoplasms were discussed. 


\section{Cancer Vaccine Strategies}

\section{Whole Cell Vaccines}

The first approach discussed was the use of whole tumor cell preparations as vaccines. Such an approach is not novel even in the neuro-oncology field, and Yancey Gillespie (Birmingham, Ala.) reviewed an unpublished study using allogeneic cell lines with standard adjuvants undertaken more than a decade ago. After promising pilot studies (Bullard et al., 1985), a prospective, randomized clinical trial that explored the efficacy of active immunization of patients newly diagnosed with MPBT with allogeneic MPBT cell lines was conducted (Mahaley, Jr. et al., 1983). Admission criteria were as follows: (1) at least one positive delayed hypersensitivity reaction to one of four recall antigens, (2) a Karnofsky rating $\geq 70$, (3) peripheral blood lymphocyte count greater than 1,000 cells $/ \mathrm{mm}^{3}$, and (4) not receiving steroids for one week prior to entry. Patients were randomized to receive monthly active immunotherapy with $1 \times 10^{8}$ lethally irradiated U-251 MG cells (Group I, 40 patients) with an initial coinjection of bacillus Calmette-Guerin cell wall adjuvant or to receive no immunization or immune stimulating therapy (Group II, 42 patients). A third group (Group III, 70 patients) who passed the screening criteria but lived too far away to return for monthly reimmunizations were immunized with live cells with adjuvant initially and were immunized monthly by their local physician with cells that had been irradiated and frozen. All patients received conventional involved field irradiation (60 Gy total dose) followed by carmustine chemotherapy $\left(80 \mathrm{mg} / \mathrm{m}^{2} \times 3\right.$ days $)$. Although there were no untoward toxicities with this therapy, there were also no significant differences in the median survivals of patients in these three groups (580 days, 580 days, and 542 days, respectively). It was concluded from this trial that while active immunotherapy using the methods employed in this study was safe, it was not effective as an immunotherapeutic approach.

The main reason for re-exploring whole tumor cell vaccine strategies is the evidence derived from studies on experimental murine and other human neoplasms that cytokines can act as potent adjuvants in this setting and produce both antibody-based and cell-mediated immune responses that are tumor-specific and cytocidal. Cytokine-based vaccines represent a novel immunotherapeutic paradigm that could be combined with conventional treatment of patients with minimal residual disease or patients expected to present tumor recurrences and may provide a means of preventing the onset of tumors in individuals with a high risk of cancer.

G. Forni (Orbassano, Italy) introduced the concept that cytokine-based whole tumor vaccines could be interpreted in at least two different ways. The first is the ex vivo transfection of tumor cells with cytokine genes and the subsequent use of these gene-modified cells, usually after lethal irradiation, as autologous or allogeneic vaccines usually delivered subcutaneously. Forni stated, however, that in his opinion, these vaccines are not a very efficient way of inhibiting the growth of established tumors. Their efficacy, in fact, decreases as a function of size and persistence of a tumor, mainly owing to its fast growth, suppressor activities, and the impenetrability of its matrix to immune attack. The other potential paradigm within the general concept of whole tumor cell vaccine strategies, is the use of systemically administered cytokines that stimulate an immune response with the tumor cells in situ acting as the vaccine. Systemic administration of recombinant IL-12, for example, has been shown to inhibit established tumors in many experimental systems. The results obtained by Forni using this approach have always superseded those he has obtained by systemic vaccination with cytokine genemodified tumor cells or by professional antigenpresenting cells pulsed with tumor antigens. It was his opinion, then, that systemic administration of cytokine would be the most effective immunotherapy approach for brain tumors.

J. S. (Durham, N.C.) then presented his experience with such whole tumor cell paradigms in a number of murine intracerebral tumor models using the B16 melanoma and the syngeneic, spontaneously arising VM/Dk murine astrocytoma models (Sampson et al., 1997; Serano et al., 1980). In both models, cytokine gene-modified tumor cells that are lethally irradiated and injected subcutaneously prevent growth of a subsequent tumor challenge or increase the survival time and cure mice with established intracerebral tumors at the time of treatment (Herrlinger et al., 1997; Sampson et al., 1996, 1998; Yu et al., 1997). The cytokine found to be most effective at the vaccine site in this paradigm was GM-CSF. Other authors have shown that this effect can be further enhanced with IL-4 at the vaccination site (Wakimoto et al., 1996). A clinical trial using GMCSF-transfected autologous MPBT cells is being planned at Duke University.

Analysis of the lymphocyte subtype infiltrating the intracerebral tumors in these models demonstrated a predominance of $\mathrm{CD} 8^{+}$cells with a dependence on $\mathrm{CD} 8^{+}$ cells for the overall effect and, interestingly, for the migration of $\mathrm{CD}^{+}{ }^{+}$cells into the brain tumor. This unique observation was complemented by work presented by P.Y. Dietrich demonstrating that the existing T-cell response to human brain tumors is predominantly an oligoclonal CD8+ cell response. Expanded clones were almost exclusively confined to the $\mathrm{CD} 8^{+}$subset. The absence of clonal expansions in the $\mathrm{CD}^{+}$population parallels the results presented by J. S. and suggests a universal defect in $\mathrm{CD} 4^{+}$migration into the CNS or of antigen presentation to $\mathrm{CD} 4{ }^{+}$cells within the CNS. 
Production of cytokine at the tumor site, either by ex vivo gene modification (Sampson et al., 1997; Thompson et al., 1996; Yu et al., 1993) or transfection in situ by direct intratumoral injection of retroviral producer cells, was also shown to be highly efficacious (Sampson et al., 1998; Wei et al., 1995). The most efficacious cytokines, when produced at the tumor site, were found to be TNF- $\alpha$, IL-2, and IL-4, although TNF- $\alpha$ was associated with some early deaths and IL-2 had a very narrow safety range.

Data similar to that provided by G. Forni for the use of systemic IL-12, except, in this case, using an intracerebral murine astrocytoma model was also presented by Sampson. The unpublished data presented demonstrated that late administration of IL-12, even at a point where mice were neurologically impaired and were losing weight as a result of their tumor, could result in complete eradication of tumor in the majority of animals with the induction of powerful immunologic memory dependent on $\mathrm{CD}^{+}$and $\mathrm{CD} 8+$ cells. It is important to note that all of these whole cell, cytokine-based vaccine paradigms were successful despite the production of biologically active TGF- $\beta$ by the murine astrocytoma cells (Sampson et al. 1997). A clinical trial using systemic or intratumoral IL-12 is currently being planned at Duke University.

A variation on the theme of cytokine-based whole cell tumor vaccines was presented by M. Bozik (Pittsburgh, Pa.). Based on preclinical work at the Pittsburgh Cancer Institute showing that live tumor cells were superior immunogens, Bozik presented his work using live tumor cells transfected with IL-4 and the thymidine kinase gene as subcutaneous vaccines. The thymidine kinase gene is inserted so that the live vaccine can later be killed by ganciclovir. Evidence was also presented, however, that such killing of tumor cells with ganciclovir may have a synergistic effect in boosting the immune response. A clinical trial, based on this approach, has received approval and will begin to accrue patients in the near future at the Pittsburgh Cancer Institute.

E.A. Chiocca (Boston, Mass.) and G. Y. Gillespie then reviewed their work and the work of others on the use of herpes simplex viral vectors. Direct transfer of herpes simplex virus vectors to CNS tumors in situ can induce a direct cytotoxic effect (Martuza et al., 1991) or, alternatively, these vectors can be used to transfer various genes with therapeutic intent to the brain tumor cells (Andreansky et al., 1996, 1997; Chambers et al., 1995; Chiocca, 1995; Kramm et al., 1996, 1997; Wei et al., 1994). Using a herpes simplex virus recombinant construct, various cytokine and prodrug activating genes have been transfected into tumor cells and have been shown to enhance the cytolytic effect of the vector alone (Toda et al., 1998)

A novel approach to whole cell vaccination in the MPBT patient using an antisense vector to inhibit one of the potent immunosuppressants secreted by malignant gliomas, TGF- $\beta$ was presented by T. Cloughesy (Los Angeles, Calif.). Preclinical studies demonstrating the efficacy of this approach have been previously reported (Fakhrai et al., 1996). At this seminar, however, Cloughesy reported on the preliminary results of a human vaccine trial using autologous tumor cells transfected with an antisense gene against TGF- $\beta$. Two patients have been treated, and both progressed within the expected time for MPBT. In addition, no changes in the inflammatory infiltrated within the tumor were identified after the vaccines.

Although R. Sobol (San Diego, Calif.) presented his experience with a single patient with a MPBT treated with subcutaneous immunizations with autologous tumor cells and fibroblasts genetically modified to secrete IL-2 by retroviral gene transfer (Sobol et al., 1995), the most extensive clinical experience with cytokine-based antitumor vaccines has been obtained in the melanoma patient population. We were fortunate at this seminar to have two experienced clinical researchers in this area. G. Parmiani (Milan, Italy) presented his data on the allogeneic melanoma cell line vaccines (Anichini et al., 1996; Arienti et al., 1996; Belli et al., 1997). Allogeneic melanoma lines were selected for expression both of human lymphocyte antigen-A2 (HLA-A2) and CTL antigens, for example MelanA/MART1, gp100, MAGE-3. Transfection of these cells with IL-2 or IL-4 genes by retroviral vectors resulted in an increase of their immunogenicity as evaluated by in vitro assays. These cytokine-producing melanoma cell lines were used, after irradiation, to vaccinate human lymphocyte antigen-A2+ patients with metastatic melanoma. In each of two clinical studies, 12 patients were treated. Only World Health Organization class I-II toxicities were observed, whereas clinical response was limited to mixed responses in 3 of 12 and 2 of 12 patients given the IL-2 and IL-4 gene transduced vaccines, respectively. In $30 \%$ of patients, an increase of anti-melanoma specific CTL activity was detected after vaccination. Thus, vaccination of metastatic melanoma patients with allogeneic, cytokine gene transduced cells resulted in a limited clinical and immunological response.

G. Dranoff (Boston, Mass.) has also initiated human clinical trials of cytokine-based whole tumor cell vaccines in the melanoma patient population. Dranoff has developed methods for the efficient retroviral transfection of short-term cultures of metastatic melanoma explants, and clinical testing of vaccination with autologous, irradiated melanoma cells engineered to secrete GM-CSF is underway at Dana-Farber Cancer Institute.

\section{Antibody-based Vaccine Strategies}

A second potential vaccination approach that was discussed at the seminar was the use of antibody 
based, or anti-idiotype vaccine strategies. D. Herlyn (Philadelphia, Pa.) introduced this concept (Herlyn et al., 1996). Anti-idiotypic antibodies functionally mimic protein or carbohydrate epitopes of tumor antigens and induce humoral, cellular, and protective immunity in animals and cancer patients (Herlyn et al., 1994; Somasundaram et al., 1995). N.-K. Cheung (New York, N.Y.) presented his data using the antiGD2 monoclonal antibody 3F8, both as a radioimmunotherapy agent and as an inducer of an idiotypic network (Cheung et al., 1994a, 1994b). N.-K. Cheung presented preclinical experiments in mice and monkeys demonstrating that rat monoclonal anti-idiotype antibodies can stimulate anti-GD2 immune responses and protect mice from tumor engraftment. His current studies are focusing on the optimization of these antiidiotype reagents for clinical trials.

\section{Dendritic Cell Strategies}

One of the newest areas of vaccine development involves the use of professional antigen presenting cells, DCs, as vaccination agents. DCs are potent antigen presenting cells of hematopoietic origin that have emerged as promising tools for cancer immunotherapy, and are capable of evoking significant anti-tumor immunity when pulsed with tumor associated peptides.

David Ashley presented the most comprehensive preclinical study of DC-based vaccines against intracerebral tumors (Ashley et al., 1997). Ashley demonstrated, using the B16/F10 murine melanoma (B16) as a model for CNS metastasis, that vaccination with bone marrow-derived DC pulsed with either B16 cell extract or B16 total RNA can induce specific CTL against B16 tumor cells. Both types of DC-based vaccines were able to protect animals from CNS tumors, and DC-based vaccines led to prolonged survival in mice treated for pre-established tumors. DC-based vaccination was associated with a dramatic enhancement of inflammatory infiltrate and large areas of hemorrhage and necrosis within the tumor. These data support the examination of DC-based vaccines for the treatment of patients with CNS tumors from which limited quantities of tumor can be derived for safe vaccine production.

H. Okada (Pittsburgh, Pa.) presented his data using DC to produce antigen-specific immune responses based on specific peptide pulsing. To explore a role for DC-based immunization strategies for the treatment of CNS tumors, a brain tumor model using the C3 sarcoma cell line which expresses the tumor-specific, MHC class I restricted peptide epitope E7(49-57) was developed. C57BL/6 mice receiving intravenous injections of bone marrow-derived DCs pulsed with E7 peptide were effectively protected against a subsequent intracerebral challenge with C3 tumor cells. More importantly, this systemic immunization strategy was also effective in a therapy model as $67 \%$ of animals $(10 / 15)$ with established (day 7) intracerebral C3 tumors treated with three weekly injections of E7 peptide-pulsed DCs achieved a long-term survival (>90 days). These findings support the hypothesis that effective CNS antitumor immune reactivity can be generated with DCbased tumor vaccines. Similar data was presented by L. Liau (Los Angeles, Calif.) using peptides eluted from MHC molecules on 9L glioma cells with mild acid and pulsed onto rat bone marrow-derived DC generated with human GM-CSF and IL-4. Liau's results demonstrated that vaccination with tumor peptide-pulsed DCs led to prolonged survival in rats with established intracranial 9L tumors implanted seven days before the initiation of vaccine therapy in vivo. T. Cloughesy also reported on the use of DCs in humans for MPBT. In Los Angeles, a single patient was treated with autologous DCs pulsed with peptides eluted from a MHC class I-matched GBM. There was no evidence of antitumor efficacy by imaging or immunohistochemical evaluation of the tumor site. However, there was a peripheral blood mononuclear cell proliferative response seen from the patient when the donor peptides were cocultured with the patients' CTLs.

In summary, the 28th Preuss Seminar on Vaccine Therapy for Malignant Primary Brain Tumors assembled world-renowned experts from diverse fields and establish the definitive knowledge base required for the development of a vaccine therapy for these tumors and initiated many new and potentially productive collaborations. From this perspective, the seminar was an overwhelming success. In addition, the questions posed at the outset of the meeting were answered in a fairly comprehensive fashion as follows.

1. Based on available evidence, it was determined that the CNS and tumors within the CNS, through a variety of mechanisms, should be considered immunologically privileged sites; however, this statement must be qualified by ample evidence that systemically induced immune responses are quite capable of eradicating tumors within this compartment.

2. Based on considerable convincing evidence from animal models, including primates, that EAE can be induced using vaccination strategies containing malignant brain tumor tissue; and, based on anecdotal reports from a number of human clinical studies that have used these approaches, it was concluded that a real risk for the induction of autoimmune disease exists with the use of vaccine strategies against MPBTs. This response is likely to exist along a quantitative spectrum with unpredictable clinical sequelae. As a result, it was concluded that an antigen-specific vaccine approach may be safer but would likely also be less efficacious. 
3. Although clear evidence exists that patients with MPBT are compromised along all arms of the immune response, it is curious that, despite this phenomenon, they do not appear to be subject to an increased incidence of opportunistic infections. The precise immunologic phenotype of brain tumor patients still needs to be more precisely defined.

Although no specific clinical trial designs were formally adopted, the consensus of the participants was that preclinical work and early vaccine therapy clinical trials should concentrate on the following areas:

1. Development of antigen-specific vaccination strategies: Such approaches could use peptides or antiidiotypic antibodies based on tumor-specific or tumor-associated antigens. These could be used in association with cytokines or other biologic adju- vants or could be pulsed onto antigen-presenting cells such as DCs.

2. Development of whole cell vaccination strategies: Although the propensity to develop EAE is likely to be a risk with such vaccines, this approach would allow the empiric identification of immunodominant rejection antigens if they exist. Whole cell approaches might use cytokine-gene modified tumor cells or DCs pulsed with whole tumor cell preparations.

Development of cytokines as chemotherapy drugs: Although systemic administration of cytokines have demonstrated only modest benefits in other cancers and previously have not been efficacious against MPBT, they represent the most potent therapies in existing animal models. As a result, the most promising cytokines should be investigated, however, and intratumoral infusion should be considered as a way of maximizing efficacy and minimizing toxicity with these agents.

\section{References}

Alleva, D.G., Burger, C.J., and Elgert, K.D. (1994) Tumor-induced regulation of suppressor macrophage nitric oxide and TNF-alpha production. Role of tumor-derived IL-10, TGF-beta, and prostaglandin E2. J. Immunol. 153, 1674-1686.

Andreansky, S.S., He, B., Gillespie, G.Y., Soroceanu, L., Markert, J., Chou, J., Roizman, B., and Whitley, R.J. (1996) The application of genetically engineered herpes simplex viruses to the treatment of experimental brain tumors. Proc. Natl. Acad. Sci. U. S. A. 93, 11313-11318.

Andreansky, S., Soroceanu, L., Flotte, E.R., Chou, J., Markert, J.M., Gillespie, G.Y., Roizman, B., and Whitley, R.J. (1997) Evaluation of genetically engineered herpes simplex viruses as oncolytic agents for human malignant brain tumors. Cancer Res. 57, 1502-1509.

Anichini, A., Mortarini, R., Maccalli, C., Squarcina, P., Fleischhauer, K., Mascheroni, L., and Parmiani, G. (1996) Cytotoxic T cells directed to tumor antigens not expressed on normal melanocytes dominate HLAA2.1-restricted immune repertoire to melanoma. J. Immunol. 156, 208-217.

Arienti, F., Sule-Suso, J., Belli, F., Mascheroni, L., Rivoltini, L., Melani, C., Maio, M., Cascinelli, N., Colombo, M.P., and Parmiani, G. (1996) Limited antitumor $\mathrm{T}$ cell response in melanoma patients vaccinated with interleukin-2 gene-transduced allogeneic melanoma cells. Hum. Gene Ther. 7, 1955-1963.

Ashley, D.M., Faiola, B., Nair, S., Hale, L.P., Bigner, D.D., and Gilboa, E. (1997) Bone marrow-generated dendritic cells pulsed with tumor extracts or tumor RNA induce antitumor immunity against central nervous system tumors. J. Exp. Med. 186, 1177-1182.

Batra, S.K., Castelino-Prabhu, S., Wikstrand, C.J., Zhu, X., Humphrey, P.A., Friedman, H.S., and Bigner, D.D. (1995) Epidermal growth factor ligandindependent, unregulated, cell-transforming potential of a naturally occurring human mutant EGFRvIII gene. Cell Growth Differ. 6, 1251-1259.

Belli, F., Arienti, F., Sule-Suso, J., Clemente, C., Mascheroni, L., Cattelan, A., Sanatonio, C., Gallino, G.F., Melani, C., Rao, S., Colombo, M.P., Maio, M., Cascinelli, N., and Parmiani, G. (1997) Active immunization of metastatic melanoma patients with interleukin-2-transduced allogeneic melanoma cells: evaluation of efficacy and tolerability. Cancer Immunol. Immunother. 44, 197-203.
Berger, T., Weerth, S., Kojima, K., Linington, C., Wekerle, H., and Lassmann, $H$. (1997) Experimental autoimmune encephalomyelitis: the antigen specificity of $\mathrm{T}$ lymphocytes determines the topography of lesions in the central and peripheral nervous system. Lab. Invest. 76, 355-364.

Biernat, W., Kleihues, P., Yonekawa, Y., and Ohgaki, H. (1997a) Amplification and overexpression of MDM2 in primary (de novo) glioblastomas. $J$. Neuropathol. Exp. Neurol. 56, 180-185.

Biernat, W., Tohma, Y., Yonekawa, Y., Kleihues, P., and Ohgaki, H. (1997b) Alterations of cell cycle regulatory genes in primary (de novo) and secondary glioblastomas. Acta. Neuropathol. (Berl) 94, 303-309.

Bigner, D.D., Pitts, O.M., and Wikstrand, C.J. (1981) Induction of lethal experimental allergic encephalomyelitis in nonhuman primates and guinea pigs with human glioblastoma multiforme tissue. J. Neurosurg. 55, 32-42.

Bloom, H.J., Peckham, M.J., Richardson, A.E., Alexander, P.A., and Payne, P.M. (1973) Glioblastoma multiforme: a controlled trial to assess the value of specific active immunotherapy in patients treated by radical surgery and radiotherapy. Br. J. Cancer 27, 253-267.

Bodmer, S., Strommer, K., Frei, K., Siepl, C., de Tribolet, N., Heid, I., and Fontana, A. (1989) Immunosuppression and transforming growth factorbeta in glioblastoma. Preferential production of transforming growth factor-beta 2. J. Immunol. 143, 3222-3229.

Bohm, C.M., Mulder, M.C., Zennadi, R., Notter, M., Schmitt-Graff, A., Finn, O.J., Taylor-Papadimitriou, J., Stein, H., Clausen, H., Riecken, E.O., and Hanski, C. (1997) Carbohydrate recognition on MUC1-expressing targets enhances cytotoxicity of a T cell subpopulation. Scandinavian J. Immunol. 46, 27-34.

Borrow, P., Cornell, J.L., Ruppe, M.D., and Mucke, L. (1995) Immunizationinduced inflammatory infiltration of the central nervous system in transgenic mice expressing a microbial antigen in astrocytes. J. Neuroimmunol. 61, 133-149.

Braun, D.P., Penn, R.D., Flannery, A.M., and Harris, J.E. (1982) Immunoregulatory cell function in peripheral blood leukocytes of patients with intracranial gliomas. Neurosurgery 10, 203-209.

Brooks, W.H., Netsky, M.G., Normansell, D.E., and Horwitz, D.A. (1972) Depressed cell-mediated immunity in patients with primary intracranial tumors. Characterization of a humoral immunosuppressive factor. J. Exp. Med. 136, 1631-1647. 
Brooks, W.H., Caldwell, H.D., and Mortara, R.H. (1974) Immune responses in patients with gliomas. Surg. Neurol. 2, 419-423.

Brooks, W.H., Roszman, T.L., and Rogers, A.S. (1976) Impairment of rosetteforming $T$ lymphoctyes in patients with primary intracranial tumors. Cancer 37, 1869-1873.

Brooks, W.H., Roszman, T.L., Mahaley, M.S., and Woosley, R.E. (1977) Immunobiology of primary intracranial tumours. II. Analysis of lymphocyte subpopulations in patients with primary brain tumours. Clin. Exp. Immunol. 29, 61-66.

Bullard, D.E., Thomas, D.G., Darling, J.L., Wikstrand, C.J., Diengdoh, J.V., Barnard, RO, Bodmer, J.G., and Bigner, D.D. (1985) A preliminary study utilizing viable HLA mismatched cultured glioma cells as adjuvant therapy for patients with malignant gliomas. Br. J. Cancer 51, 283-289.

Burger, P.C., Heinz, E.R., Shibata, T., and Kleihues, P. (1988) Topographic anatomy and $\mathrm{CT}$ correlations in the untreated glioblastoma multiforme. $J$. Neurosurg. 68, 698-704.

Chambers, R., Gillespie, G.Y., Soroceanu, L., Andreansky, S., Chatterjee, S., Chou, J., Roizman, B., and Whitley, R.J. (1995) Comparison of genetically engineered herpes simplex viruses for the treatment of brain tumors in a scid mouse model of human malignant glioma. Proc. Natl. Acad. Sci. U. S. A. 92, 1411-1415.

Cheung, N.K., Cheung, I.Y., Canete, A., Yeh, S.J., Kushner, B., Bonilla, M.A., Heller, G., and Larson, S.M. (1994a) Antibody response to murine antiGD2 monoclonal antibodies: correlation with patient survival. Cancer Res. 54, 2228-2233.

Cheung, N.K., Kushner, B.H., Yeh, S.J., and Larson, S.M. (1994b) $3 F 8$ monoclonal antibody treatment of patients with stage IV neuroblastoma: A phase II study. Prog. Clin. Biol. Res. 385, 319-328.

Chiocca, E.A. (1995) Brain tumor gene therapy in mice with a novel "suicide" gene: the cyclophosphamide-activating CYP2B1 gene. Clin. Neurosurg. 42, 370-382.

de Martin, R., Haendler, B., Hofer-Warbinek, R., Gaugitsch, H., Wrann, M., Schlusener, H., Seifert, J.M., Bodmer, S., Fontana, A., and Hofer, E. (1987) Complementary DNA for human glioblastoma-derived T cell suppressor factor, a novel member of the transforming growth factor-beta gene family. EMBO J. 6, 3673-3677.

Elliott, L., Brooks, W., and Roszman, T. (1987) Role of interleukin-2 (IL-2) and IL-2 receptor expression in the proliferative defect observed in mitogenstimulated lymphocytes from patients with gliomas. J. Natl. Cancer Inst. 78, 919-922.

Elliott, L.H., Brooks, W.H., and Roszman, T.L. (1987) Activation of immunoregulatory lymphocytes obtained from patients with malignant gliomas. J. Neurosurg. 67, 231-236.

Elliott, L.H., Brooks, W.H., and Roszman, T.L. (1990) Inability of mitogen-activated lymphocytes obtained from patients with malignant primary intracranial tumors to express high affinity interleukin 2 receptors. J. Clin. Invest. 86, 80-86.

Elliott, L.H., Brooks, W.H., and Roszman, T.L. (1992) Suppression of high affinity IL-2 receptors on mitogen activated lymphocytes by glioma-derived suppressor factor. J. Neurooncol. 14, 1-7.

Fakhrai, H., Dorigo, O., Shawler, D.L., Lin, H., Mercola, D., Black, K.L., Royston, I and Sobol, R.E. (1996) Eradication of established intracranial rat gliomas by transforming growth factor beta antisense gene therapy. Proc. Natl. Acad. Sci. U. S. A. 93, 2909-2914.

Finn, O.J., Jerome, K.R., Henderson, R.A., Pecher, G., Domenech, N., Magarian-Blander, J., and Barratt-Boyes, S.M. (1995) MUC-1 epithelial tumor mucin-based immunity and cancer vaccines. Immunol. Rev. 145, 61-89.

Fontana, A., Hengartner, H., de Tribolet, N., and Weber, E. (1984) Glioblastoma cells release interleukin 1 and factors inhibiting interleukin 2mediated effects. J. Immunol. 132, 1837-1844.

Herlyn, D., Harris, D., Zaloudik, J., Sperlagh, M., Maruyama, H., Jacob, L., Kieny, M.P., Scheck, S., Somasundaram, R., Hart, E. (1994)
Immunomodulatory activity of monoclonal anti-idiotypic antibody to anticolorectal carcinoma antibody CO17-1A in animals and patients. J. Immunother. Emphasis Tumor Immunol. 15, 303-311.

Herlyn, D., Somasundaram, R., Li, W., and Maruyama, H. (1996) Anti-idiotype cancer vaccines: past and future. Cancer Immunol. Immunother. 43, 65-76.

Herrlinger, U., Kramm, C.M., Johnston, K.M., Louis, D.N., Finkelstein, D., Reznikoff, Dranoff, G., Breakefield, X.O., and Yu, J.S. (1997) Vaccination for experimental gliomas using GM-CSF-transduced glioma cells. Cancer Gene Ther. 4, 345-352.

Hishii, M., Nitta, T., Ishida, H., Ebato, M., Kurosu, A., Yagita, H., Sato, K., and Okumura, K. (1995) Human glioma-derived interleukin-10inhibits antitumor immune responses in vitro. Neurosurgery 37, 1160-1167.

Hoshimaru, M., Ray, J., Sah, D.W., and Gage, F.H. (1996) Differentiation of the immortalized adult neuronal progenitor cell line HC2S2 into neurons by regulatable suppression of the v- myc oncogene. Proc. Natl. Acad. Sci. U. S. A. 93, 1518-1523.

Huang, H.S., Nagane, M., Klingbeil, C.K., Lin, H., Nishikawa, R., Ji, X.D., Huang, C.M., Gill, G.N., Wiley, H.S., and Cavenee, W.K. (1997) The enhanced tumorigenic activity of a mutant epidermal growth factor receptor common in human cancers is mediated by threshold levels of constitutive tyrosine phosphorylation and unattenuated signaling. J. Biol. Chem. 272, 2927-2935.

Huettner, C., Paulus, W., and Roggendorf, W. (1995) Messenger RNA expression of the immunosuppressive cytokine IL-10 in human gliomas. Am. J. Pathol. 146, 317-322.

Imperato, J.P., Paleologos, N.A., and Vick, N.A. (1990) Effects of treatment on long-term survivors with malignant astrocytomas. Ann. Neurol. 28, 818-822.

Kelly, P.J., Daumas-Duport, C., Scheithauer, B.W., Kall, B.A., and Kispert, D.B. (1987) Stereotactic histologic correlations of computed tomography- and magnetic resonance imaging-defined abnormalities in patients with glial neoplasms. Mayo Clin. Proc. 62, 450-459.

Kramm, C.M., Rainov, N.G., Sena-Esteves, M., Chase, M., Pechan, P.A., Chiocca, E.A., and Breakefield, X.O. (1996) Herpes vector-mediated delivery of marker genes to disseminated central nervous system tumors. Hum. Gene Ther. 7, 291-300.

Kramm, C.M., Chase, M., Herrlinger, U., Jacobs, A., Pechan, P.A., Rainov, N.G., Sena-Esteves, M., Aghi, M., Barnett, F.H., Chiocca, E.A., and Breakefield, X.O. (1997) Therapeutic efficiency and safety of a secondgeneration replication-conditional HSV1 vector for brain tumor gene therapy. Hum.Gene Ther. 8, 2057-2068.

Linington, C., Berger, T., Perry, L., Weerth, S., Hinze-Selch, D., Zhang, Y., Lu, HC, Lassmann, H., and Wekerle, H. (1993) T cells specific for the myelin oligodendrocyte glycoprotein mediate an unusual autoimmune inflammatory response in the central nervous system. Eur. J. Immunol. 23, 1364-1372.

Mahaley, M.S., Jr., Brooks, W.H., Roszman, T.L., Bigner, D.D., Dudka, L., Richardson and S. (1977) Immunobiology of primary intracranial tumors. Part 1: studies of the cellular and humoral general immune competence of brain-tumor patients. J. Neurosurg. 46, 467-476.

Mahaley, M.S., Jr., Bigner, D.D., Dudka, L.F., Wilds, P.R., Williams, D.H., Bouldin, TW, Whitaker, J.N., and Bynum, J.M. (1983a) Immunobiology of primary intracranial tumors. Part 7: Active immunization of patients with anaplastic human glioma cells: a pilot study. J. Neurosurg. 59, 201-207.

Mahaley, M.S., Jr., Gillespie, G.Y., Gillespie, R.P., Watkins, P.J., Bigner, D.D., Wikstrand, C.J., MacQueen, J.M., and Sanfilippo, F. (1983b) Immunobiology of primary intracranial tumors. Part 8: Serological responses to active immunization of patients with anaplastic gliomas. J. Neurosurg. 59, 208-216.

Martuza, R.L., Malick, A., Markert, J.M., Ruffner, K.L., and Coen, D.M. (1991) Experimental therapy of human glioma by means of a genetically engineered virus mutant. Science 252, 854-856. 
McKay, R. (1997) Stem cells in the central nervous system. Science 276, 66-71.

Menzies, C.B., Gunar, M., Thomas, D.G., and Behan, P.O. (1980) Impaired thymus-derived lymphocyte function in patients with malignant brain tumour. Clin. Neurol. Neurosurg. 82, 157-168.

Miescher, S., Whiteside, T.L., Carrel, S., and von Fliedner, V. (1986) Functional properties of tumor-infiltrating and blood lymphocytes in patients with solid tumors: effects of tumor cells and their supernatants on proliferative responses of lymphocytes. J. Immunol. 136, 1899-1907.

Morford, L.A., Elliott, L.H., Carlson, S.L., Brooks, W.H., and Roszman, T.L. (1997) T cell receptor-mediated signaling is defective in T cells obtained from patients with primary intracranial tumors. J. Immunol. 159, 4415-4425.

Moscatello, D.K., Holgado-Madruga, M., Godwin, A.K., Ramirez, G., Gunn, G., Zoltick, P.W., Biegel, J.A., Hayes, R.L., and Wong, A.J. (1995) Frequent expression of a mutant epidermal growth factor receptor in multiple human tumors. Cancer Res. 55, 5536-5539.

Nagane, M., Coufal, F., Lin, H., Bogler, O., Cavenee, W.K., Huang and H.J. (1996) A common mutant epidermal growth factor receptor confers enhanced tumorigenicity on human glioblastoma cells by increasing proliferation and reducing apoptosis. Cancer Res. 56, 5079-5086.

Nishikawa, R., Ji, X.D., Harmon, R.C., Lazar, C.S., Gill, G.N., Cavenee, W.K., Huang and H.J. (1994) A mutant epidermal growth factor receptor common in human glioma confers enhanced tumorigenicity. Proc. Natl. Acad. Sci. U. S. A. 91, 7727-7731.

Pasteur, L. (1885) Methode pour prevenir la rage apres morsure. Comptes rendus de l'academie des sciences (Paris) 101, 765-774.

Remlinger, P. (1904) Contribution a l'etude de la toxine rabique (faits experimentaux et clinique). Compt. rend. Soc. de Biol. 56, 346-350.

Remlinger, P. (1905) Accidents paralytiques au cours du traitement antirabique. Ann. Inst. Pasteur 19, 625-646.

Reyes-Mugica, M., Rieger-Christ, K., Ohgaki, H., Ekstrand, B.C., Helie, M., Kleinman, G., Yahanda, A., Fearon, E.R., Kleihues, P., and Reale, M.A. (1997) Loss of DCC expression and glioma progression. Cancer Res. 57, 382-386.

Romine, J.S., and Salk, J. (1983) A study of myelin basic protein as a therapeutic probe in patients with multiple sclerosis. In: Hallpike, J.F., Adams, C.W.M., and Toutellotte, W.W. (Eds.), Multiple Sclerosis: pathology, diagnosis, and management. Baltimore: Williams \& Wilkins. pp. 621-630.

Roszman, T.L., and Brooks, W.H. (1980) Immunobiology of primary intracranial tumours. III. Demonstration of a qualitative lymphocyte abnormality in patients with primary brain tumours. Clin. Exp. Immunol. 39, 395-402.

Roszman, T.L., Brooks, W.H., and Elliott, L.H. (1982) Immunobiology of primary intracranial tumors. VI. Suppressor cell function and lectin-binding lymphocyte subpopulations in patients with cerebral tumors. Cancer 50 , 1273-1279.

Roszman, T.L., Elliott, L.H., and Brooks, W.H. (1992) Proliferative potential of T-cell lymphocytes from gliomas. J. Neurosurg. 77, 820-821.

Saas, P., Walker, P.R., Hahne, M., Quiquerez, A.L., Schnuriger, V., Perrin, G., French, L., Van Meir, E.G., de Tribolet, N., Tschopp, J., and Dietrich, P.Y. (1997) Fas ligand expression by astrocytoma in vivo: maintaining immune privilege in the brain? J. Clin. Invest. 99, 1173-1178.

Sampson, J., Bigner, D., and Dranoff, G. (1998) Cytokine-based gene therapy for brain tumors. In: Chiocca, E.A., and Breakefield, X.O. (Eds.), Gene Therapy for Neurological Disorders and Brain Tumors. Totowa, New Jersey: Humana Press, pp. 231-294.

Sampson, J.H., Archer, G.E., Ashley, D.M., Fuchs, H.E., Hale, L.P., Dranoff, G., and Bigner, D.D. (1996) Subcutaneous vaccination with irradiated, cytokine-producing tumor cells stimulates $\mathrm{CD} 8^{+}$cell-mediated immunity against tumors located in the "immunologically privileged" central nervous system. Proc. Natl. Acad. Sci. U. S. A. 93, 10399-10404.

Sampson, J.H., Ashley, D.M., Archer, G.E., Fuchs, H.E., Dranoff, G., Hale, L.P., and Bigner, D.D. (1997) Characterization of a spontaneous murine astro- cytoma and abrogation of its tumorigenicity by cytokine secretion. Neurosurgery 41, 1365-1373.

Serano, R.D., Pegram, C.N., and Bigner, D.D. (1980) Tumorigenic cell culture lines from a spontaneous VM/Dk murine astrocytoma (SMA). Acta. Neuropathol.(Berl.) 51, 53-64.

Sobol, R.E., Fakhrai, H., Shawler, D., Gjerset, R., Dorigo, O., Carson, C., Khaleghi, T., Koziol, J., Shiftan, T.A., and Royston, I. (1995) Interleukin-2 gene therapy in a patient with glioblastoma. Gene Ther. 2, 164-167.

Somasundaram, R., Zaloudik, J., Jacob, L., Benden, A., Sperlagh, M., Hart, E., Marks, G., Kane, M., Mastrangelo, M., and Herlyn, D. (1995) Induction of antigen-specific $\mathrm{T}$ and $\mathrm{B}$ cell immunity in colon carcinoma patients by anti-idiotypic antibody. J. Immunol. 155, 3253-3261.

Stuart, G., and Krikorian, K. (1930) A fatal neuro-paralytic accident of antirabies treatment. Lancet 1, 1123-1125.

Thomas, D.G., Lannigan, C.B., and Behan, P.O. (1975) Impaired cell-mediated immunity in human brain tumours. Lancet 1, 1389-1390. (Letter)

Thompson, R.C., Pardoll, D.M., Jaffee, E.M., Ewend, M.G., Thomas, M.C., Tyler, B.M., and Brem, H. (1996) Systemic and local paracrine cytokine therapies using transduced tumor cells are synergistic in treating intracranial tumors. J. Immunother. Emphasis. Tumor Immunol. 19, 405-413.

Toda, M., Martuza, R.L., Kojima, H., and Rabkin, S.D. (1998) In situ cancer vaccination: an IL-12 defective vector/replication-competent herpes simplex virus combination induces local and systemic antitumor activity. J. Immunol. 160, 4457-4464.

Tohma, Y., Gratas, C., Van Meir, E.G., Desbaillets, I., Tenan, M., Tachibana, O., Kleihues, P., and Ohgaki, H. (1998) Necrogenesis and Fas/APO-1 (CD95) expression in primary (de novo) and secondary glioblastomas. J. Neuropathol. Exp. Neurol. 57, 239-245.

Trouillas, P. (1973) Immunology and immunotherapy of cerebral tumors. Current status. Rev. Neurol. (Paris) 128, 23-38.

Tuohy, V.K., Lu, Z.J., Sobel, R.A., Laursen, R.A., and Lees, M.B. (1988) A synthetic peptide from myelin proteolipid protein induces experimental allergic encephalomyelitis. J. Immunol. 141, 1126-1130.

Wakimoto, H., Abe, J., Tsunoda, R., Aoyagi, M., Hirakawa, K., and Hamada, $H$. (1996) Intensified antitumor immunity by a cancer vaccine that produces granulocyte-macrophage colony-stimulating factor plus interleukin. Cancer Res. 56, 1828-1833.

Waksman, B.H., Porter, H., Lees, M.D., Adams, R.D., and Folch, J. (1954) A study of the chemical nature of components of bovine white matter effective in producing allergic encephalomyelitisin the rabbit. J. Exp. Med. 100, 451-471.

Watanabe, K., Tachibana, O., Sata, K., Yonekawa, Y., Kleihues, P., and Ohgaki, H. (1996) Overexpression of the EGF receptor and p53 mutations are mutually exclusive in the evolution of primary and secondary glioblastomas. Brain Pathol. 6, 217-224.

Wei, M.X., Tamiya, T., Chase, M., Boviatsis, E.J., Chang, T.K., Kowall, N.W., Hochberg, FH, Waxman, D.J., Breakefield, X.O., and Chiocca, E.A. (1994) Experimental tumor therapy in mice using the cyclophosphamide-activating cytochrome P450 2B1 gene. Hum. Gene Ther. 5, 969-978.

Wei, M.X., Tamiya, T., Hurford, R.K., Jr., Boviatsis, E.J., Tepper, R.I., and Chiocca, E.A. (1995) Enhancement of interleukin-4-mediated tumor regression in athymic mice by in situ retroviral gene transfer. Hum. Gene Ther. 6, 437-443.

Wekerle, H., Kojima, K., Lannes-Vieira, J., Lassmann, H., and Linington, C. (1994) Animal models. Ann. Neurol. 36 (Suppl.), S47-53.

Wikstrand, C.J., Hale, L.P., Batra, S.K., Hill, M.L., Humphrey, P.A., Kurpad, S.N., McLendon, R.E., Moscatello, D., Pegram, C.N., Reist, C.J., Traweek, S.T., Wong, A.J., Zalutsky, M.R., and Bigner, D.D. (1995) Monoclonal antibodies against EGFRvIII are tumor specific and react with breast and lung carcinomas and malignant gliomas. Cancer Res. 55, 3140-3148.

Wong, A.J., Ruppert, J.M., Bigner, S.H., Grzeschik, C.H., Humphrey, P.A., Bigner, D.D., and Vogelstein, B. (1992) Structural alterations of the epi- 
dermal growth factor receptor gene in human gliomas. Proc. Natl. Acad. Sci. U. S. A. 89, 2965-2969.

Wrann, M., Bodmer, S., de Martin, R., Siepl, C., Hofer-Warbinek, R., Frei, K., Hofer, E., and Fontana, A. (1987) T cell suppressor factor from human glioblastoma cells is a $12.5-\mathrm{kd}$ protein closely related to transforming growth factor-beta. EMBO J. 6, 1633-1636.

Young, H.F., Sakalas, R., and Kaplan, A.M. (1976) Inhibition of cell-mediated immunity in patients with brain tumors. Surg. Neurol. 5, 19-23.
Yu, J.S., Wei, M.X., Chiocca, E.A., Martuza, R.L., and Tepper, R.I. (1993) Treatment of glioma by engineered interleukin 4-secreting cells. Cancer Res. 53, 3125-3128.

Yu, J.S., Burwick, J.A., Dranoff, G., and Breakefield, X.O. (1997) Gene therapy for metastatic brain tumors by vaccination with granulocytemacrophage colony-stimulating factor-transduced tumor cells. Hum. Gene Ther. 8, 1065-1072. 